Journal of Organometallic Chemistry, 127 (1977) 45-54

(c) Elsevier Sequoia S.A., Lausanne - Printed in The Netherlands

\title{
REACTIONS OF BIS(HEXAMETHYLBENZENE)IRON(0) WITH CARBON MONOXIDE AND WITH UNSATURATED HYDROCARBONS
}

\author{
SHARON R. WEBER * and HANS H. BRINTZINGER ** \\ Department of Chemistry. The University of Michigan, Ann Arbor, Michigan 48104 (U.S.A.). \\ and Fachbereich Chemie, Universität Konstanz, D 7750 Konstanz (West Germany) \\ (Received July-19th, 1976)
}

\section{Summary}

Thermal decomposition of bis(hexamethylbenzene)iron(0) in the presence of carbon monoxide yields a novel carbonyl iron complex, $\left[\mathrm{C}_{6}\left(\mathrm{CH}_{3}\right)_{6}\right] \mathrm{Fe}(\mathrm{CO})_{2}$. The cyclohexadiene complex $\left[\mathrm{C}_{6}\left(\mathrm{CH}_{3}\right)_{6}\right] \mathrm{Fe}\left(\mathrm{C}_{6} \mathrm{H}_{8}\right)$ is obtained from reaction of bis(hexamethylbenzene)iron( 0 ) with either 1,3-cyclohexadiene or benzene, and the yield is much greater in the presence of hydrogen gas. Interaction of bis(hexamethylbenzene)iron( 0 ) with 2-butyne induces a catalytic cyclotrimerization to give more hexamethylbenzene. Kinetic and isotope distribution studies indicate that the primary step in these reactions is not a direct loss of one ring ligand, but rather an insertion of the iron center into one of the ligand methyl $\mathrm{C}-\mathrm{H}$ bonds, leading to a benzyl hydride complex species. Mechanisms for the subsequent reactions of this iron hydride species are proposed.

\section{Introduction}

We recently investigated some of the pathways available for stoichiometric and catalytic reactions of the cyclopentadienylcobalt(I) half-sandwich system [1]. This 14-electron core structure, with two coordination sites available for a variety of reactions, shows interesting analogies to as well as characteristic differences from comparable reaction systems based on other 14-electron transition metal sandwich cores. We have now investigated the reactivity patterns of reaction systems based on an isoelectronic arene-iron(0) half-sandwich structure. Hexamethylbenzeneiron( 0 ) requires two ligand electron pairs to complete its 18 electron valence shell and also contains its metal in a low oxidation state susceptible to oxidative addition by relatively inert substrates. It should thus

- Present address, Siena Hights Colleze, Adrian, Michigan, U.S.A.

* To whom correspondence should be addressed at Universitat Konstinz, 7750 Konstanz, B.R.D. 
exhibit interesting reactions, potentially applicable to homogeneous catalysis.

A useful entry into such arene-iron(0) reaction systems appeared to be available via thermal decomposition of bis(hexamethylbenzene)iron(0) (I) a 20 valence-electron species, reported by Fischer and Röhrscheid to be light and temperature sensitive [2]. We describe below studies of the reactions which occur when the decomposition is carried out in the presence of various substrates.

\section{Results}

\section{Reaction of I with carbon monoxide}

Solutions of the bis(arene) complex $I$ in petroleum ether decay to hexamethylbenzene and metallic iron at $20^{\circ} \mathrm{C}$ with a half life of about 5 days. If canbon monoxide is admitted, however, the color of I disappears fairly rapidly, with a half life of about $8 \mathrm{~min}$. Removal of solvent and subsequent fractional sublimation (first at $20^{\circ} \mathrm{C}$ to remove hexamethylbenzene, then at $40^{\circ} \mathrm{C}$ ) gives $\left[\mathrm{C}_{6}-\right.$ $\left(\mathrm{CH}_{3}\right)_{6} \mathrm{Fe}(\mathrm{CO})_{2}$ (II). This compound is characterized by two IR absorptions at 1954 and $1892 \mathrm{~cm}^{-1}$, by the appropriate parent and fragment ions in its mass spectrum, and by an NMR spectrum with a sharp singlet at $\tau 8.21 \mathrm{ppm}$, indicating the equivalence of all the methyl groups present $*$.

The kinetics of the reaction between bis(arene)iron(0) (I) and $\mathrm{CO}$ to form II were studied spectroscopically at $\mathrm{CO}$ pressures between 4 and $12 \mathrm{~atm}$. at $21^{\circ} \mathrm{C}$. The reaction is first order in $I$, but independent of $C O$ concentrations in the range of $4 \times 10^{-2}$ to $1.4 \times 10^{-1} \mathrm{M}$, the rate constant being $8.3 \times 10^{-2} \mathrm{~min}^{-1}$. This result must mean that $C O$ is not involved in the rate-limiting step, which must therefore occur either before or after CO attack. An essentially saturated pre-equilibrium between I and $\mathrm{CO}$ to form a monocarbonyl complex, the decomposition of which then governs the rate, would be conceivable but can be ruled out, since the spectrum of $I$ is initially unchanged in the presence of $\mathrm{CO}$. We must thus assume that the rate-determining step for the $C O$ reaction is the formation of some intermediate, which in the absence of $\mathrm{CO}$ is in reversible equilibrium with the starting material $I$. This intermediate cannot be the half-sandwich hexamethylbenzeneiron( 0 ), since neither the decomposition of $I$, nor its reaction with $\mathrm{CO}$ is significantly inhibited by an excess of hexamethylbenzene in solution up to the its saturation concentration. Such an inhibition would be observable if the equilibrium:

$$
\left[\mathrm{C}_{6}\left(\mathrm{CH}_{3}\right)_{6}\right]_{2} \mathrm{Fe} \rightleftharpoons\left[\mathrm{C}_{6}\left(\mathrm{CH}_{3}\right)_{6}\right] \mathrm{Fe}+\mathrm{C}_{6}\left(\mathrm{CH}_{3}\right)_{6}
$$

determined the rate of subsequent reactions. We thus conclude that this intermediate III still contains all the components, and so is an isomer, of the starting material I. This intermediate, the identity of which is to be discussed in more

\footnotetext{
- Synthesis of a dimer of this species. $\left.\left[\text { [ }_{6}\left(\mathrm{CH}_{3}\right)_{6}\right\}_{\mathrm{Fe}}(\mathrm{CO})_{2}\right]_{2}$ : was reported by Fischer et al. [3]. No equilibrium was observed between this dimer and the monomer reported here. Preliminary mass spectral and NMR data obtained on the dimeric carbonyl indicate that this species might have a composition $\left[\left\{\mathrm{C}_{6}\left(\mathrm{CH}_{3}\right)_{6} \mathrm{H}\right]_{\mathrm{Fe}}(\mathrm{CO})_{2}\right]_{2}$ : such a cyclohexadienyl species, obtained by single hydrogenation of each arene ring, would also allow for a metal-metal bond, usually associnted with bridging carbonyl ligands [4].
} 
detail below, then appears to undergo a subsequent ligand exchange, which is fast at all $\mathrm{CO}$ pressures studied, to form the dicarbonyl II.

\section{Reaction of I with 1,3-cyclohexadiene}

If the decomposition of $I$ is carried out at $40^{\circ} \mathrm{C}$ in neat 1,3 -cyclohexadiene, the diene complex $\left[\mathrm{C}_{6}\left(\mathrm{CH}_{3}\right)_{6}\right] \mathrm{Fe}\left(\mathrm{C}_{6} \mathrm{H}_{8}\right)(\mathrm{IV})$ is obtained in about $67 \%$ yield after removal of excess diene and of hexamethylbenzene. This complex is characterized by a mass spectrum with a parent peak at m/e 298 and fragment peaks at $m / e 218\left(\left[\mathrm{C}_{6}\left(\mathrm{CH}_{3}\right)_{6}\right] \mathrm{Fe}^{+}\right), 162\left(\left[\mathrm{C}_{6}\left(\mathrm{CH}_{3}\right)_{6}\right]^{+}\right)$and $147\left(\left[\mathrm{C}_{6}\left(\mathrm{CH}_{3}\right)_{5}\right]^{+}\right)$. The NMR spectrum exhibits a sharp singlet at $\tau 8.01$ ppm due to 18 equivalent methyl protons, and a double doublet at $\tau 6.00 \mathrm{ppm}$ due to the "central" diene protons, as well as unresolved multiplets at $\tau 8.30$ and $8.60 \mathrm{ppm}$ due, respectively, to the "terminal" diene protons and the four methylene protons *. The formation of IV at $20^{\circ} \mathrm{C}$ from 1 in pure cyclohexadiene occurs with a first-order rate constant of $6.8 \times 10^{-3} \mathrm{~min}^{-1}$. This reaction is slower by an order of magnitude than the decomposition of $\mathrm{I}$ in the presence of $\mathrm{CO}$. We conclude, that cyclohexadiene is less efficient than $\mathrm{CO}$ in facilitating loss of hexamethylbenzene from the intermediate III.

\section{Reaction of I with 2-butyne.}

Decomposition of bis(arene)iron( 0 ) (I), in petroleum ether at $45^{\circ} \mathrm{C}$ in the presence of a ninetyfold excess of 2-butyne leads to the formation of additional hexamethylbenzene. After a reaction time of $42 \mathrm{~h} 5 \mathrm{mmol}$ of $\mathrm{C}_{6}\left(\mathrm{CH}_{3}\right)_{6}$ are obtained per mmol of starting material 1 . Even after subtraction of $1-2 \mathrm{mmoles}$ of $\mathrm{C}_{6}\left(\mathrm{CH}_{3}\right)_{6}$ formed by decomposition of $\mathrm{I}$, a significant amount of the 2-butyne used must have undergone catalytic trimerization to $\mathrm{C}_{6}\left(\mathrm{CH}_{3}\right)_{6}$.

A fraction containing a yellow-brown material can be sublimed from the reaction mixture. This material exhibits a parent ion at $m / e, 326$ and a fragment ion at $m / e 218$ in its mass spectrum corresponding to a composition $\left[\mathrm{C}_{6}\left(\mathrm{CH}_{3}\right)_{6}\right] \mathrm{Fe}$ $\left[\mathrm{C}_{4}\left(\mathrm{CH}_{3}\right)_{4}\right](\mathrm{V})$. It could, thus be an iron-hexamethylbenzenecyclobutadiene complex. We could not isolate and further characterize this material however, because of the small yields and the difficulties encountered in separating it from the large excess of hexamethylbenzene present.

\section{Reaction of I with arene solvents and hydrogen}

Decomposition of $I$ in benzene always leads to formation of small amounts (ca. 3\%) of the cyclohexadiene complex IV, while decomposition in toluene leads to the methyl homologue $\left[\mathrm{C}_{6}\left(\mathrm{CH}_{3}\right)_{6}\right] \mathrm{Fe}\left(\mathrm{C}_{6} \mathrm{H}_{7} \mathrm{CH}_{3}\right)$. These products wereidentified by their mass spectra.

That the two extra hydrogen atoms gained in the conversion of benzene to a cyclohexadiene ligand are largely derived from the hexamethylbenzene rings of I is established by the isotopic distribution of this product formed in benzene- $d_{6}$; more than half of the newly acquired hydrogen atoms being found to consist of ' $\mathrm{H}$.

Admission of hydrogen to the reaction mixture of $I$ in benzene induces a rather dramatic increase in the yields of cyclohexadiene complex IV; about

\footnotetext{
- Lergely similar NMR data have been reported for $\left(\mathrm{C}_{6} \mathrm{H}_{8}\right) \mathrm{Fe}(\mathrm{CO})_{3}$ [5].
} 
$50-60 \%$ of I is now converted to IV, compared will 3-5\% in the absence of hydrogen. At the same time, the fraction of ${ }^{1} \mathrm{H}$ in the two extra hydrogens in the product obtained from benzene- $d_{6}$ rises to over $90 \%$, indicating an efficient utilization of $\mathrm{H}_{2}$ gas for the hydrogenation of the benzene substrate. Similar results were obtained in a reaction with $D_{2}$ gas and undeuterated benzene- $h_{6}$ -

Undoubtedly, in the decomposition of $I$, some iron-hydride intermediate is formed which can then transfer its hydrogen ligands to an arene. In the presence of both benzene and hydrogen gas, such a hydride intermediate leads to a preponderant conversion of compound I to the cyclohexadiene compound IV.

Further information on the course of the hydrogen transfer reaction is obtained from an analysis of the stereochemistry of the resulting cyclohexadiene complex. Studies on NMR spectra of related cyclo-diene complexes have been described $[5,6]$ and it appears certain that the exo-and endo positions of such a complex differ significantly in their respective chemical shifts. The methylene hydrogen signals in $\left[\mathrm{C}_{6}\left(\mathrm{CH}_{3}\right)_{6}\right] \mathrm{Fe}\left(\mathrm{C}_{6} \mathrm{D}_{6} \mathrm{H}_{2}\right)$ (prepared with $\mathrm{H}_{2}$ gas) appear exclusively on the high-field side of the quartet of methylene proton peaks, and partial deuteration leads to partial disappearance of this high-field part of the complex methylene spectrum. We conclude that the two incoming hydrogen atoms are transferred to the same side of the newly formed cyclohexadiene ligand, although we do not know whether they are both in exo, or both in endo position. $A$ cis-hydrogen transfer to unsaturated substrates is common in homogeneous hydrogenations; in our case it is readily explained by successive transfer of two hydrogen ligands from some hydride-containing intermediate to a coordinated benzene molecule.

Decay of $I$ in benzene, under vacuum or 1 atm of $N_{2}$, occurs with a half-life of $10 \mathrm{~h}$ at $20^{\circ} \mathrm{C}$. The reaction rate $\left(1.15 \times 10^{-3} \mathrm{~min}^{-1}\right)$ is intermediate between that for decay of $I$ in alkanes $\left(1 \times 10^{-4} \mathrm{~min}^{-1}\right)$ and in cyclohexadiene $\left(6.8 \times 10^{-3}\right.$ $\min ^{-1}$ ). In the presence of $1 \mathrm{~atm}$ of $\mathrm{H}_{2}$, the rate of decay of $\mathrm{I}$ in benzene is the same as that under vacuum or $\mathbf{N}_{2}$.

\section{Discussion}

An essential point of our study is the identity of the intermediate III, which appears to exist in a reversible isomerisation equilibrium with $I$, and apparently undergoes rapid conversion to the dicarbonyl II in the presence of CO. For the rate determining, primary. isomerisation step, two possibilities appear particularly plausible. First, one of the aromatic rings could rearrange to a geometry with only one or two double bonds coordinated to the iron atom (IA), such as that observed in the stable form of the analogous bis(arene) ruthenium(0) complex $\left[\mathrm{C}_{6}\left(\mathrm{CH}_{3}\right)_{6}\right]_{2} \mathrm{Ru}[7,8]$. Alternatively, the intermediate in could be a benzyl hydride species $\left[\mathrm{C}_{6}\left(\mathrm{CH}_{3}\right)_{6}\right] \mathrm{Fe}\left(\mathrm{H}_{3}\left[\mathrm{CH}_{2} \mathrm{C}_{6}\left(\mathrm{CH}_{3}\right)_{5}\right]\right.$, derived from I by the insertion of the iron atom into one of the ligand $\mathrm{C}-\mathrm{H}$ bonds (IB), analogous to the insertions observed e.g. with decamethyl titanocene derivatives [9]. Such a species could attain an 18-electron configuration by the coordination of an allylic ring segment occasionally observed with benzyl complexes [10]. The rate data obtained for the reaction of $\mathrm{I}$ with $\mathrm{CO}$ indicate that the rate-limiting step in the reaction with $\mathrm{CO}$, which eventually leads to the dicarbonyl complex II, is probably an isomerisation of I to the benzyl hydride species IB. 
The constancy of the rate of formation of II at different CO pressuses indicates that at these $\mathrm{CO}$ pressures the reconversion of the crucial isomerisation product to the original structure I does not compete with its conversion to the carbonyl complex II. It follows that under these conditions the observed rate of formation of II $\left(8.3 \times 10^{-2} \mathrm{~min}^{-1}\right)$ is equal to the rate of isomerisation of $I$ to III. A mere distortion of the axially symmetric structure I to an unsymmetrically $\pi$-coordinated benzene complex is unlikely to yield a forward rate constant of only about $8 \times 10^{-2} \mathrm{~min}^{-1}$. That the regeneration of $I$ from IA is slow in comparison to carbonyl complex formation is even less likely. For the analogous bis(hexamethylbenzene)ruthenium $(0)$ complex, for which a distorted tetrahapto structure of one of the benzene rings has been established from crystal structure data [8] and from NMR spectra at lower temperatures, the NMR data at room temperature are consistent with an interconversion of coordinated and uncoordinated ring positions which is rapid on the NMR time scale [7]. Conversion of $I$ to IB by insertion of the iron atom into a $\mathrm{C}-\mathrm{H}$ bond, on the other hand, is a reasonable possibility for an isomerisation with a rate similar to the observed rate of formation of $\mathrm{II}$, and with a reverse reaction too slow to compete against the bimolecular reaction with $\mathrm{CO}$.

SCHEME 1. Possible structures fox intermediate $\mathrm{III}:-\mathrm{O}=-\mathrm{CH}_{3}$ -

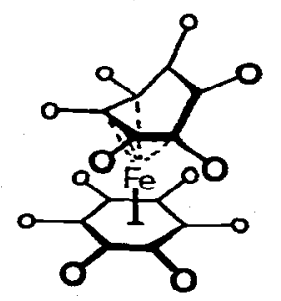

$\dot{4}$

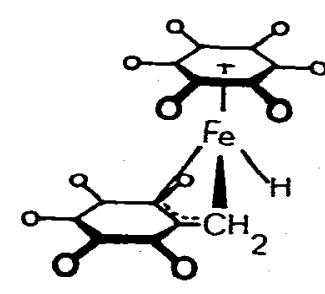

5

Additional evidence for the occurrence of a benzylhydride intermediate in the thermal decomposition of $I$ is derived from the observation that small but significant amounts of hydrogen gas (ca. $0.05 \mathrm{~mol} / \mathrm{mol}$ of I) are reproducibly formed during the decomposition of $I$, and that the organic decomposition product, mainly hexamethylbenzene, always contains some bis(pentamethylphenyl) ethane, $\left(\mathrm{CH}_{3}\right)_{5} \mathrm{C}_{6} \mathrm{CH}_{2} \mathrm{CH}_{2} \mathrm{C}_{6}\left(\mathrm{CH}_{3}\right)_{5}$ as shown by mass spectrometry. These two products are to be expected if a ligand exchange between two units of IB occasionally precedes the reductive elimination of hydride and benzyl ligand groups.

The occurrence of a benzyl hydride species as an intermediate in thermal reactions of I can be rationalized as follows. Direct elimination of hexamethylbenzene from the 20 -electron species I would generate the highly unstable, monomeric 14-electron species $\left[\mathrm{C}_{6}\left(\mathrm{CH}_{3}\right)_{6}\right] \mathrm{Fe}(\mathrm{O})$. Through isomerisation of $\mathrm{I}$ to an intermediate with structure IB, on the other hand, reaction paths which involve only 16- and 18-electron species are available. Conversion of structure IB to a monohapto-benzyl structure [11], uptake of a CO ligand, and subsequent reductive elimination of hexamethylbenzene from the 18-electron intermediate $\left[\mathrm{C}_{6}\left(\mathrm{CH}_{3}\right)_{6}\right] \mathrm{Fe}(\mathrm{CO}) \mathrm{H}\left[h^{2}-\mathrm{CH}_{2} \mathrm{C}_{6}\left(\mathrm{CH}_{3}\right)_{5}\right]$ can generate the 16-electron species $\left[\mathrm{C}_{6}\left(\mathrm{CH}_{3}\right)_{6}\right] \mathrm{Fe}(\mathrm{CO})$. Other ligands, such as 2-butyne or 1,3-cyclohexadiene could 
react in the same way with IB and thus convert it to an 18-electron monohaptobenzyl hydride, again facilitating the elimination of hexamethylbenzene by circumvention of an otherwise required 14-electron intermediate. The observed acceleration of the decay of $I$ by these substrates is therefore clearly comparible with the intervention of intermediate III (structure IB) in the formation of products IV and V as well as in that of II, as summarized in Scheme 2 . In the reaction of 2-butyne, a common intermediate for the formation of both $\mathrm{V}$ and the extra hexamethylbenzene might be a metallocyclopentadiene species similar to those observed in related $\left(\mathrm{C}_{5} \mathrm{H}_{5}\right)$ Co half-sandwich system [1]. From such an intermediate, formation of a cyclobutadiene compound $\mathrm{V}$ or coordination of an additional 2-butyne molecule, with subsequent regeneration of $I$ could occur as competing reactions. Repeated regeneration of $I$ by coordination of acetylene ligands, followed by decay to III and acetylene-assisted hexamethylbenzene elimination, would provide a satisfactory explanation for the catalytic acetylene trimerization.

SCHEME 2 . Proposed pathways for decomposition of $I$ and for reactions of intermediate III with various substrate molecules in the formation of dicarbonyl complex II. diene complex IV, and of a complex $\mathrm{V}$ which probably contains a cyclobutadiene ligand. Intermediate III was not observed directly and is postulated primarily on the basis of kinetic data (see text): $-\mathrm{O}=-\mathrm{CH}_{3}: \mathrm{HMB}=\mathrm{C}_{6}\left(\mathrm{CH}_{3}\right)_{6}$.

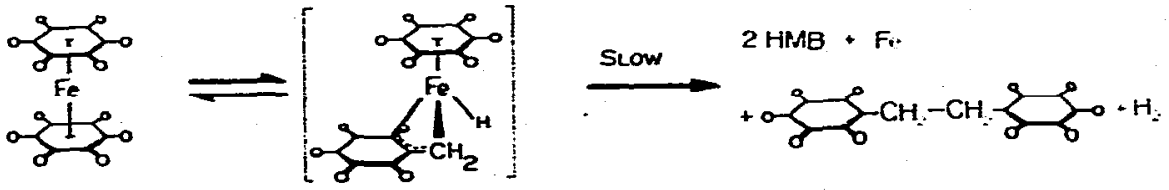

(I)
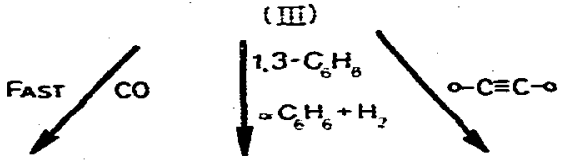

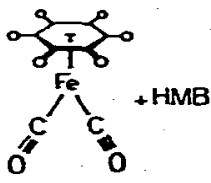

(II)

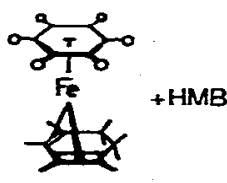

(IV)

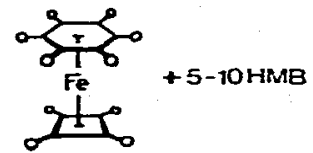

$(\mathbb{Z})$

As for the incorporation of benzene into the 1,3-hexadiene compound IV which occurs even in the absence of $\mathrm{H}_{2}$, a hydride intermediate such as III would provide a reasonable pathway for the observed transfer of $\mathrm{C}_{6}\left(\mathrm{CH}_{3}\right)_{6}$ protons to an arene molecule. The question whether the arene substrates interact with intermediate III directly or rather with a secondary hydride complex derived from it remains unanswered, as does that concerning the kind of hydride species involved in the incorporation of molecular $\mathrm{H}_{2}$ into the $1,3-\mathrm{C}_{6} \mathrm{H}_{8}$ complex. In this respect, it is significant that in the presence of excess $D_{2}$ gas, $66 \%$ of the two extra hydrogen atoms are still found to be ${ }^{1} \mathrm{H}$. Since the solvent provides virtually no hydrogen in this transfer, it appears that even in the presence of molecular hydrogen the hexamethylbenzene ligand is still the major source of hy- 
drogen atoms transferred. This indicates that a ligand-derived hydride such as III must intervene even in the hydrogen-assisted conversion of benzene into a $\mathrm{C}_{6} \mathrm{H}_{8}$ ligand; excess $\mathrm{H}_{2}$ or $\mathrm{D}_{2}$ appears to favour some sort of hydride structure derived from III, so as to make its reaction with benzene near-stoichiometric.

Interestingly, a stable tetrameric hydride $\left(\mathrm{C}_{5} \mathrm{H}_{5}\right)_{4} \mathrm{Co}_{4} \mathrm{H}_{4}$ has been isolated for the related isoelectronic cobalt(I) half-sandwich system [12]. The non-accumulation of hexamethylbenzeneiron( 0 ) hydrides in the absence of a reducible substrate makes their identification difficult, but this very instability is, of course, an essential feature of their participation in efficient hydride transfer reactions.

\section{Experimental}

\section{General techniques used}

All manipulations were carried out under nitrogen or argon, using Schlenk or high-vacuum techniques.

Aluminum bromide and sodium (reagent grade, Merck), naphthalene (scintillation grade, Merck), hexamethylbenzene (pure grade, Roth) and iron(II) bromide (Alfa Inorganics) were used without further purification. 1,3-Cyclohexadiene (EGA-Chemie), 2-butyne (Chemical Procurement Laboratories) and all solvents (reagent grade, Merck) were doubly distilled, and stored under vacuum over a suitable drying and deoxygenating agent.

Visible, IR, NMR and mass spectra were recorded on normal commercial instruments. Mass spectra were recorded at several different ionization voltages, usually down to a nominal voltage of $30 \mathrm{eV}$, to minimize fragmentation.

\section{(1) Preparation of $\left[\mathrm{C}_{6}\left(\mathrm{CH}_{3}\right)_{6}\right]_{2} \mathrm{Fe}(\mathrm{O}) *$}

A suspension of $5.0 \mathrm{~g}(7.5 \mathrm{mmol})$ of dry $\left[\mathrm{C}_{6}\left(\mathrm{CH}_{3}\right)_{6}\right]_{2} \mathrm{Fe}$ (II) $\left(\mathrm{PF}_{6}\right)_{2}$ (prepared according to $[13,14]), 0.50 \mathrm{~g}$ napthalene, and $0.52 \mathrm{~g}(23 \mathrm{mmol})$ of sodium in $100 \mathrm{ml}$ of tetrahydrofuran was stirred at room temperature. The solid phase slowly turned purple. After a few hours a dark brown solution formed, but the solid phase remained. After about $8 \mathrm{~h}$, the solid phase was also black. (The Teflon stir bar becomes black owing to residual sodium naphthalene when the reaction is complete.)

The tetrahydrofuran was removed in vacuo. The naphthalene was sublimed out at $40^{\circ} \mathrm{C}$ during $12 \mathrm{~h}$, and the residue transferred to a Soxhlet extractor (adapted for work under grease-free vacuum conditions by replacing ground joints and stopcocks with O-ring joints and Teflon valves). Extraction with pentane was carried out at approximately $20^{\circ} \mathrm{C}$ in a partial vacuum until the extracting solvent was colourless.

The black solid was removed from the extract by filtration under argon, washed three times with $10 \mathrm{ml}$ portions of pentane, and dried thoroughly in vacuo, to give a yield of $1.53 \mathrm{~g}(54 \%)$ of $\left(\mathrm{C}_{6}\left(\mathrm{CH}_{3}\right)_{6}\right)_{2} \mathrm{Fe}(0)$. The IR spectrum

\footnotetext{
* Preparation of bis(hexamethylbenzene)iron(0) as described in ref. 2 yields pure material, but in small yields. Alternative methods of reduction of the di-cation lead to the formation of variable amounts of a dihydrogenated side product. $\left[\mathrm{C}_{6}\left(\mathrm{CH}_{3}\right)_{6}\right]\left[\mathrm{C}_{6}\left(\mathrm{CH}_{3}\right)_{6} \mathrm{H}_{2}\right] \mathrm{Fe}(\mathrm{O})$. In the sodium naphthalide reduction used here, production of this impurity is is low enough to allow its complete removal (as judged by its absence from the mass spectrum of the remaining material) by several washines of the product with petroleum ether.
} 
agreed with that previously reported [2]. The mass spectrum showed a parent ion at $m / e 380$ and fragment ions at $m / e 218\left[\left(\mathrm{C}_{6}\left(\mathrm{CH}_{3}\right)_{6}\right) \mathrm{Fe}\right]^{+}$and at $m / e 162$ $\left[\left(\mathrm{C}_{6}\left(\mathrm{CH}_{3}\right)_{6}\right]^{+}\right.$.

(2) Reaction of $\left[\mathrm{C}_{6}\left(\mathrm{CH}_{3}\right)_{6}\right]_{2} \mathrm{Fe}(\mathrm{O})$ with carbon monoxide

A solution of $294 \mathrm{mg}(0.775 \mathrm{mmol})$ of $\left(\mathrm{C}_{6}\left(\mathrm{CH}_{3}\right)_{6}\right)_{2} \mathrm{Fe}(0)$ in $40 \mathrm{ml}$ of petroleum ether was exposed to $3.44 \mathrm{mmol}$ of carbon monoxide on a vacuum manifold and stirred at $40^{\circ} \mathrm{C}$ for $16 \mathrm{~h}$, during which the solution turned pale brown and a pale brown precipitate formed. Unreacted carbon monoxide (1.69 mmol) was removed with a Toepler pump; $\mathrm{CO}$ uptake: $1.75 \mathrm{mmol} \mathrm{CO} / \mathrm{mmol}\left[\mathrm{C}_{6}\left(\mathrm{CH}_{3}\right)_{6}\right]_{2-}$ $\mathrm{Fe}(0)$. Removal of the petroleum ether in vacuo left a purple-brown residue. Hexamethylbenzene and the orange dicarbonyl product were sublimed out at $60^{\circ} \mathrm{C}$. Resublimation at $20^{\circ} \mathrm{C}$ removed the hexamethylbenzene, and the hexamethylbenzeneiron dicarbonyl was then resublimed at $40^{\circ} \mathrm{C}$. A yield of $126 \mathrm{mg}$ $(60 \%)$ of $\left[\mathrm{C}_{6}\left(\mathrm{CH}_{3}\right)_{6}\right] \mathrm{Fe}(\mathrm{CO})_{2}$ is obtained. Its mass spectrum shows a parent peak at $m / e 274$ with major fragments at $m / e 246,218$ and 162 . Other spectral properties of this compound are discussed above.

\section{Reaction of $\left(\mathrm{C}_{6}\left(\mathrm{CH}_{3}\right)_{6}\right)_{2} \mathrm{Fe}(\mathrm{O})$ with 1,3-cyclohexadiene}

Degassed and dried cyclohexadiene (10 ml) was distilled in vacuo on to $357 \mathrm{mg}$ $(0.94 \mathrm{mmol})$ of $\left[\mathrm{C}_{6}\left(\mathrm{CH}_{3}\right)_{6}\right]_{2} \mathrm{Fe}(0)$. The solution was stirred at $40^{\circ} \mathrm{C}$ for $48 \mathrm{~h}$, during which the solution remained dark brown. After removal of the cyclohexadiene in vacuo, the hexamethylbenzene and the orange product were subblimed out at $40^{\circ} \mathrm{C}$. In a slow resublimation, the hexamethylbenzene was removed at $17^{\circ} \mathrm{C}$, followed by sublimation of the $\left[\mathrm{C}_{6}\left(\mathrm{CH}_{3}\right)_{6}\right]\left(\mathrm{C}_{6} \mathrm{H}_{8}\right) \mathrm{Fe}(0) \mathrm{com}$ plex at $25^{\circ} \mathrm{C}$. The yield of hexamethylbenzene(cyclohexadiene)iron(0) was $193 \mathrm{mg}(67 \%)$. The Nujol-mull infrared spectrum of the product agrees well with that of $\left(\mathrm{C}_{6} \mathrm{H}_{6}\right)\left(\mathrm{C}_{6} \mathrm{H}_{8}\right) \mathrm{Fe}(0)[6]$ when account is taken of the differing aromatic rings: The main absorptions of IV occur at $1310 \mathrm{~m}, 1250 \mathrm{~m}, 1160 \mathrm{~s}, 1058 \mathrm{~m}$, $990 \mathrm{~m}, 844 \mathrm{~m}$ and $822 \mathrm{~m} \mathrm{~cm}^{-1}$. Other spectral properties of this complex are discussed above.

\section{Reaction of $\left[\mathrm{C}_{6}\left(\mathrm{CH}_{3}\right)_{6}\right]_{2} \mathrm{Fe}(\mathrm{O})$ with 2-butyne}

Approximately $1 \mathrm{mmol}$ of $\left(\mathrm{C}_{6}\left(\mathrm{CH}_{3}\right)_{6}\right)_{2} \mathrm{Fe}(0)$ was dissolved in $50 \mathrm{ml}$ of petrokeum ether. About $90 \mathrm{mmol}$ of 2-butyne was distill in, and the solution was stirred at $45^{\circ} \mathrm{C}$ for $42 \mathrm{~h}$, after which a large amount of white precipitate was present with the dark brown solution. The IR and NMR spectra of the precipitate, after filtration and recrystallization, showed it to be pure hexamethylbenzene. A total of $790 \mathrm{mg}$ ( $4.9 \mathrm{mmol})$ of hexamethylbenzene was recovered.

The filtrate from this reaction gave, in addition to hexamethylbenzene, a very small amount of brown-gold sublimate at $40^{\circ} \mathrm{C}$, which shows two peaks in the mass spectrum at m/e 326 and 218. The m/e 326 peak is consistent with a formulation $\left[\mathrm{C}_{6}\left(\mathrm{CH}_{3}\right)_{6}\right]\left[\mathrm{C}_{4}\left(\mathrm{CH}_{3}\right)_{4}\right] \mathrm{Fe}(0)$.

\section{Thermal decomposition of $\left[\mathrm{C}_{6}\left(\mathrm{CH}_{3}\right)_{6}\right]_{2} \mathrm{Fe}(\mathrm{O})$ in alkanes}

A solution of $320 \mathrm{mg}(0.60 \mathrm{mmol})$ of $\left[\mathrm{C}_{6}\left(\mathrm{CH}_{3}\right)_{6}\right]_{2} \mathrm{Fe}(0)$ in $50 \mathrm{ml}$ of cyclohexane was stirred at $80^{\circ} \mathrm{C}$ for $40 \mathrm{~h}$, during which time a gray-black precipitate formed and the solution becomes pale gold. Collection of evolved gas with a 
Toepler pump indicated that $0.037 \mathrm{mmol}$ was generated, and the gas was identified as hydrogen by conversion into $\mathrm{H}_{2} \mathrm{O}$ in a CuO tube at $310^{\circ} \mathrm{C}$. After removal of cyclohexane and sublimation of hexamethylbenzene a dark gray material was left, and was metallic iron, judged by its magnetism.

\section{Thermal decomposition of $\left[\mathrm{C}_{6}\left(\mathrm{CH}_{3}\right)_{6}\right]_{2} \mathrm{Fe}(\mathrm{O})$ in benzene}

A solution of $307 \mathrm{mg}(0.81 \mathrm{mmol})$ of $\left[\mathrm{C}_{6}\left(\mathrm{CH}_{3}\right)_{6}\right]_{2} \mathrm{Fe}(0)$ in $30 \mathrm{ml}$ of benzene is stirred at $60^{\circ} \mathrm{C}$ for $5 \mathrm{~h}$, after which it was pale in colour. $0.05 \mathrm{mmol}$ of hydrogen was evoled $\left(0.06 \mathrm{mmol} \mathrm{H}_{2} / \mathrm{mmol}\left[\mathrm{C}_{6}\left(\mathrm{CH}_{3}\right)_{6}\right]_{2} \mathrm{Fe}(0)\right)$ and metallic iron produced. Filtration of the solution and removal of the benzene in vacuo gave a pale orange product, which sublimed at $25^{\circ} \mathrm{C}$. The mass and NMR spectra indicated that this sublimate is a mixture of hexamethylbenzene and $\left[\mathrm{C}_{6}\left(\mathrm{CH}_{3}\right)_{6}\right]\left(\mathrm{C}_{6} \mathrm{H}_{8}\right) \mathrm{Fe}(0)$ (IV). The yield of the latter product after further purification was $3-5 \%$.

\section{Thermal decomposition of $\left[\mathrm{C}_{6}\left(\mathrm{CH}_{3}\right)_{6}\right]_{2} \mathrm{Fe}(\mathrm{O})$ in deuterated benzene}

When the above reaction is carried out in deuterated benzene, a deuterated analog of the cyclohexadiene complex is obtained. Mass spectral evidence indicates that $66.2 \%$ of the added hydrogen atoms are ${ }^{2} \mathrm{H}$.

\section{Thermal decomposition of $\left[\mathrm{C}_{6}\left(\mathrm{CH}_{3}\right)_{6}\right]_{2} \mathrm{Fe}(\mathrm{O})$ in deuterated benzene in the presence of $\mathrm{H}_{2}$}

A solution of $188.0 \mathrm{mg}(0.495 \mathrm{mmol})$ of $\left[\mathrm{C}_{6}\left(\mathrm{CH}_{3}\right)_{6}\right]_{2} \mathrm{Fe}(0)$ in $15 \mathrm{ml}$ of deuterated benzene was stirred under $1.97 \mathrm{mmol}$ of $\mathrm{H}_{2}$ at $45^{\circ} \mathrm{C}$ for $12 \mathrm{~h}$. The solution became orange and a dark precipitate formed, some of which was metallic iron. Removal of residual $\mathrm{H}_{2}$ with a Toepler pump showed that $0.30 \mathrm{mmol}$ of hydrogen were taken up during the experiment $\left(0.61 \mathrm{mmol} \mathrm{H}_{2} / \mathrm{mmol}\left[\mathrm{C}_{6}\right.\right.$ $\left.\left.\left(\mathrm{CH}_{3}\right)_{6}\right]_{2} \mathrm{Fe}(0)\right)$. A yield of $81 \mathrm{mg}(54 \%)$ of $\left[\mathrm{C}_{6}\left(\mathrm{CH}_{3}\right)_{6}\right]\left(\mathrm{C}_{6} \mathrm{D}_{6+n} \mathrm{H}_{2-n}\right) \mathrm{Fe}(0)$ was obtained. The mass spectrum showed that only $6.9 \%$ of the hydrogen atoms taken up by the benzene substrate were deuterium.

9. Thermal decomposition of $\left[\mathrm{C}_{6}\left(\mathrm{CH}_{3}\right)_{6}\right]_{2} \mathrm{Fe}(\mathrm{O})$ in benzene in the presence of $\mathrm{D}_{2}$

When the above experiment was carried out in $\mathrm{C}_{6} \mathrm{H}_{6}$ under deuterium, the corresponding products were obtained in similar yields but $34.1 \%$ of the added hydrogens were deuterium.

10. Kinetics of the reaction of $\left[\mathrm{C}_{6}\left(\mathrm{CH}_{3}\right)_{6}\right]_{2} \mathrm{Fe}(\mathrm{O})$ with carbon monoxide

The kinetics were observed at pressures of from 4 to 12 atm $C O$, providing solutions with a $\mathrm{CO}$ concentration between $4.64 \times 10^{-2} \mathrm{M}$ and $1.39 \times 10^{-1} \mathrm{M}$, at a constant temperature of $21^{\circ} \mathrm{C}$.

Typically, $15 \mathrm{ml}$ of a $5 \times 10^{-4} \mathrm{M}$ solution of $\left[\mathrm{C}_{6}\left(\mathrm{CH}_{3}\right)_{6}\right]_{2} \mathrm{Fe}(0)$ was syringed into a high-pressure cell with $5 \mathrm{~cm}$ pathlength. An initial absorption measurement was taken at $650 \mathrm{~nm}$. Carbon monoxide was added to the cell at the appropriate pressure and the disappearance of the $650 \mathrm{~nm}$ absorption was measured as a function of time. Plots of $\ln \left(c-c_{\infty}\right)$ vs. time for each experiment yielded first order rate constants in the range of $7 \times 10^{-2}$ to $10.7 \times 10^{-2} \mathrm{~min}^{-1}$; the reproducibility of the rate constants was within $\pm 25 \%$.

\section{Kinetics of reactions of $\left[\mathrm{C}_{6}\left(\mathrm{CH}_{3}\right)_{6}\right]_{2} \mathrm{Fe}(\mathrm{O})$ without gaseous reactants}

A $1 \mathrm{~cm}$ cell was used for the decomposition of $\left[\mathrm{C}_{6}\left(\mathrm{CH}_{3}\right)_{6}\right]_{2} \mathrm{Fe}(0)$ in petroleum 
ether and the reactions with benzene and cyclohexadiene. The rate of decay of the peak at $465 \mathrm{~nm}$ was recorded.

\section{Acknowledgements}

Financial support of this work by the National Science Foundation (GP33130X), by Deutsche Forschungsgemeinschaft and by Fonds der Chemischen Industrie is gratefully acknowledged.

\section{References}

1 W.S. Lee and H.H. Brintzinger. J. Organometal. Chem., 127 (1977) 87. 93.

2 E.O. Fischer and F. Röhrscheid, Z. Naturforsch. B. 17 (1962) 483.

3 E.O. Fischer, W. Berngruber and C.G. Kreiter, J. Organorietal. Chem., 14 (1968) P25.

4 F.A. Cotton and D.L. Hunter, Inorz. Chem., 13 (1974) 2044.

5 R. Burton, L. Fratt and G. Wilkinson, J. Chem. Soc., (1961) 594.

6 E.O. Fischer and J. Müller, Z. Naturforsch. B, 17 (1962) 776: K. Moseley and P.M. Maitlis, Chem. Commun., (1969) 616; M.L.H. Green. L. Pratt, and G. Wilkinson, J. Chem. Soc.. (1959) 3753: P.H. Bird and M.R. Churehill. Chem. Commun., (1967) 777: G. Winkhaus. I.. Pratt and G. Wilkinson. J. Chem. Soc., (1961) 3807.

7 E.O. Fischer and C. Elschenbroich, Chem. Ber., 103 (1970) 162.

8 G. Huttner, S. Lange and E.O. Fischer, Angew. Chem., 83 (1971) 579.

9 J.E Bereaw, J. Amer. Chem. Soc., 96 (1974) 5087.

10 R.B. King and A. Fronzaglia, J. Amer. Chem. Soc.. 88 (1966) 709.

11 F.A. Cotton and T.J. Marks, J. Amer. Chem. Soc., 91 (1969) 1339.

12 J. Müller and H. Dorner. Angew. Chem.. 85 (1973) 867.

13 E.O. Fischer and R. Böttcher, Chem. Ber., 89 (1956) 2397.

14 J.F. Helling and D.M. Braitsch, J. Amer. Chem. Soc., 92 (1970) 7207. 